\title{
Neuropharmacological effects of Albizzia chinensis extract
}

\author{
Naresh Gupta ${ }^{1}$, Dinesh Kansal ${ }^{2}$ * \\ ${ }^{\mathbf{1}}$ Associate Professor, ${ }^{2}$ Professor and HOD, ${ }^{\mathbf{1}, 2}$ Dept.of Pharmacology, ${ }^{\mathbf{1}}$ Dr. Radhakrishnan Government Medical College, \\ Hamirpur, Himachal Pradesh, ${ }^{2}$ Dr. Rajendra Prasad Government Medical College, Kangra, Himachal Pradesh, India
}

\section{*Corresponding Author:}

Email: dinesh.kansal56@gmail.com

\begin{abstract}
Introduction: To know the neuropharmacological effects of Albizzia chinensis extract in rats and mice.

Materials and Methods: The test compound was evaluated experimentally for its neuropharmacological activities in rats and mice. Blind neuropharmacological screening, potentiation of barbiturate hypnosis, stimulation of the central nervous system, maximal electroshock and pentylenetetrazol induced convulsions, analgesic activity were studied.

Results: The compound potentiated pentobarbital hypnosis, reduced spontaneous motor activity, antagonized amphetamine induced hyperactivity, blocked the conditioned avoidance response without affecting the unconditioned response and showed analgesic activity by the tail-flick method but not in hot plate model in the experimental animals.

Conclusion: The compound is similar to chlorpromazine and morphine.
\end{abstract}

Keyword: Saponin, Central nervous system, Animals.

\section{Introduction}

The active constituents of vegetable drugs are various, like alkaloids, glycosides, saponins, oils, fats, waxes, resins, oleoresins, gums, balsams, lipids and tannins etc. The saponins, though in wide use in the Chinese system of medicine had not earlier got the attention that they seem to deserve. The plant Albizzia chinensis Merr. (syn A.stipulata), commonly known as "Oee" in Himachal Pradesh belongs to the family Leguminosae and the sub-family Mimoseae. It is a large deciduous tree, the leaves of which are used as supplementary fodder in winter. However, the plant has been in use as a lotion for cuts, scabies and other skin diseases, but has not been subjected to pharmacological studies so far. It is precisely for this reason that it has been taken up for the present study.

\section{Plan of Study}

The test compound was evaluated experimentally for its neuropharmacological activities in rats and mice. The study was conducted according to the following general plan. Initially blind neuropharmacological screening was carried out. On the basis of the results of this, the effects on the central nervous system (CNS) were studied. This included effects on general behavior, potentiation of barbiturate hypnosis, stimulation of the central nervous system, maximal electroshock and pentylenetetrazol induced convulsions, analgesic activity and psychopharmacological studies.

\section{Materials and Methods}

The various effects/activities on CNS of the test compound were studied on rats and albino mice. The animals were housed in cages which were kept in clean and airy rooms. Room heating was provided in harsh winter months. They were fed on sprouted green gram routinely.
Free access to water was allowed. They were however fasted on the day prior to some of the experiments. The average weight of the rats was 100-225 gms and that of mice was 15-40 gms. Animals of the same strain but of either sex were used.

The drugs used were morphine sulphate, pentobarbitone sodium, pentylenetetrazol (PTZ), sodium salicylate, amphetamine, phenytoin sodium, trimethadione and chlorpromazine (CPZ). Stock solutions of various drugs were prepared in distilled water. The final dilutions were, however, made in normal saline just before use. The test substance was the saponin albichinoside (ALB) obtained from the plant Albizzia chinensis. The test drug was injected intraperitoneally.

1. Blind Neuropharmacological Studies Screening: (Irwin, 1959). ${ }^{1}$ The test substance was administered to albino mice ranging in weight from $15-40 \mathrm{gms}$ in the doses of $1.0 \mathrm{mg} / \mathrm{kg}$ and $5.0 \mathrm{mg} / \mathrm{kg}$. The volume dose was $10.0 \mathrm{ml} / \mathrm{kg}$. The normal behavior and activity of the mice was recorded before the administration of drugs. After the drug injections the behavior and activity were recorded at 15 minute intervals for two hours, at 30 minute intervals for the next two hours and at hourly intervals for the next 4 hours. Final observations were made after 24 hours and the overnight mortality was also recorded.

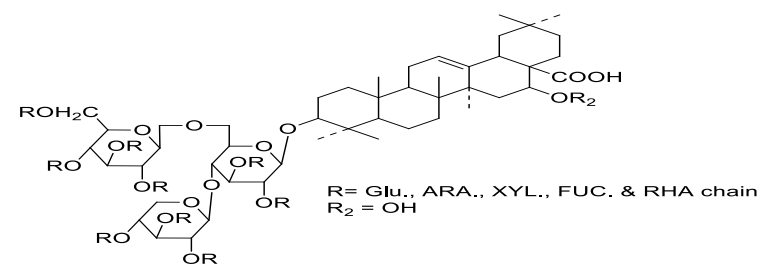

Fig. 1: Chemical structure of albichinoside (ALB) 
2. Potentiation of Barbiturate Hypnosis: (Kuhn and van Mannen, 1961) $)^{2}$ The above method was used with slight modifications in that the barbiturate used was pentobarbitone sodium (Piala, High, Hassert, Burke and Craver, 195933 Brazada and Bauccum, 19614). The albino mice were weighed, marked and divided into three groups of five animals each. The first group was given normal saline only, the second chlorpromazine and third albichinoside $(5.0 \mathrm{mg} / \mathrm{kg})$. Inj. pentobarbitone sodium was given in a dose of $35.0 \mathrm{mg} / \mathrm{kg} 45$ minutes later. The time of loss of righting reflex, as well as, its recovery was noted and the difference was taken to be the sleeping time. The mice were checked every five minutes for the recovery of the righting reflex by gently manipulating them.

3. Spontaneous Motor Activity (Harris \& Uhle, 1961) The method used for this was a little variation on the basic protocol followed by Harris \& Uhle (1961) because the Techno photoactometer used had six photovoltaic cells and, therefore, the number of light beams was six (Uski and Sugeno, 1967). ${ }^{6}$ Three groups of albino mice consisting of five animals each were used. Acclimatization of the animals to the instrument was carried out by placing them in it for 10 minutes. The normal activity count of the animals was taken thrice at 0,30 and 60 minutes for 10 minutes each and the average was determined. Animals showing gross over or under activity were rejected and replaced. The three groups were then given normal saline, chlorpromazine (5.0 $\mathrm{mg} / \mathrm{kg})$ and albichinoside $(5.0 \mathrm{mg} / \mathrm{kg})$ respectively, intraperitoneally. The volume dose was $5.0 \mathrm{ml} / \mathrm{kg}$. The activity counts were then again taken at 30 minute intervals for two hours and at hourly intervals for another two hours.

4. Antagonism of Amphetamine induced Hyperactivety (Harris and Uhle, 1961) ${ }^{5}$ For this experiment also 10 minute activity counts were taken. Three groups of albino mice with 5 animals each were used. After acclimatization their normal activity counts were taken at 0 and 30 minutes and the average activity were determined. One group was then given normal saline, another chlorpromazine $(5.0 \mathrm{mg} / \mathrm{kg})$ and the third albichinoside $(5.0 \mathrm{mg} / \mathrm{kg})$ in a volume dose of 5.0 $\mathrm{ml} / \mathrm{kg}$ ). The activity count was again taken at 0 and 30 minutes and the average determined. One hour later amphetamine $(4.5 \mathrm{mg} / \mathrm{kg})$ was given to all the groups i.p. and the activity counts were again taken at 30 minute intervals for two hours and then at hourly intervals for two hours.

5. Conditioned Avoidance Response (Piala, High, Hassert, Burke and Craver, 1959) $)^{3}$ The apparatus used was similar to that described by Cook and Weidley (1957). ${ }^{7}$ The current, delivered through the grid was approximately $0.1 \mathrm{~mA}$ of 60 cycles $\mathrm{AC}$ at $40 \mathrm{~V}$. The conditioned stimulus was provided with a buzzer built into the apparatus.

Albino rats of either sex were selected at random and trained individually to climb a pole (unconditioned response) by delivering an electric shock for 30 seconds. They were later conditioned to do like-wise at the sound of the buzzer for 12 seconds (conditioned response). The shock was delivered to them if they did not respond to the buzzer. This schedule was continued for 15 days and rats not responding properly were rejected. A final trial was given on the day of the experiment.

The selected rats were divided into six groups of 10 animals each. They were injected with normal saline, chlorpromazine $(5.0 \mathrm{mg} / \mathrm{kg})$ and albichinoside $(2.5,5.0$, $10.0,20.0 \mathrm{mg} / \mathrm{kg}$ ) respectively, intraperitoneally. The response of the animals was then observed at hourly intervals for 5 hours. Three trials were given for each response.

\section{Analgesic Effect}

a. Tail Flick Method (Davies, Walpole and Raventos, 1946) ${ }^{8}$ This experiment was performed with a Techno analgesiometer. The radiant heat stimulus was delivered with a nitrochrome wire heated with a current of $6 \mathrm{~V}$. The albino rats were put into a rat holder and the tail, about 2 inches away from the root, was held over the heated wire. The rat responded by flicking the tail when the heat became unbearable.

A number of rats were screened and those showing a reaction time between 6-10 seconds were selected for the actual experiment. The animals were divided into 3 groups of 5 animals each and their tail flick latency was recorded. The first group was then given normal saline, the second morphine $(5.0 \mathrm{mg} / \mathrm{kg})$ and third albichinoside $(5.0 \mathrm{mg} / \mathrm{kg})$ in a volume of $10.0 \mathrm{ml} / \mathrm{kg}$, i.p. The reaction time of the animals was then observed at 15 minutes intervals for one hour.

b. Hot-plate Method (Jacob and Bosvski, 1961) ${ }^{9}$ For this experiment the hot-plate designed by Eddy and Leimbach $(1953)^{10}$ was used. However, the temperature of the plate was maintained at $65^{\circ} \mathrm{C}$ as salicylate is active at this temperature. The albino mice were individually placed on the hot-plate and their latency for licking their hind-paws was recorded. Those showing a latency of around 6 seconds were selected for the actual experiment.

The animals were then divided into three groups of five animals each. One group was given normal saline, the second sodium salicylate $(400.0 \mathrm{mg} / \mathrm{kg})$ and the third albichinoside $(5.0 \mathrm{mg} / \mathrm{kg})$ i.p. They were then individually placed on the hot-plate and their latency for licking the hind-paw, jumping and leaping was noted. In the absence of any reaction the cut-off time was 45 seconds. The responses were taken at 5, 10, 15 and 30 minutes. The volume dose was $5.0 \mathrm{ml} / \mathrm{kg}$.

\section{Anti-convulsant Effect}

a. Maximal Electroshock induced Convulsions (MES) (Toman, Swinyard and Goodman, 1946) ${ }^{11}$ Albino rats of either sex were divided into 3 groups of 5 animals each. They were then held securely and corneal electrodes, previously dipped in normal saline, were placed on their eyes. A DC current of $1 \mathrm{~m}$ sec duration, $100 / \mathrm{sec}$ frequency and $140 \mathrm{~V}$ amplitude was delivered to 
them for 0.3 second only. The duration of various components of the seizure pattern was noted. The various components were flexion, extension, clonus and post-ictal depression. The first group was given normal saline, the second phenytoin sodium $(60.0 \mathrm{mg} / \mathrm{kg})$ and the third albichinoside $(5.0 \mathrm{mg} / \mathrm{kg})$ respectively, i.p. After 45 minutes the shock was again delivered as earlier and the pattern of the seizure and the duration of its components were noted.

b. Pentylenetetrazole induced Convulsions (PTZ) (Soage-Echague and Lim, 1962): ${ }^{12}$ Healthy fasting rats of weights between 130-160 gms were selected and divided into three groups of five animals each. One group was given the vehicle only; the second was given trimethadione $(500.0 \mathrm{mg} / \mathrm{kg})$ and the third was given albichinoside $(5.0 \mathrm{mg} / \mathrm{kg})$. After 45 minutes pentylenetetrazol $(112.0 \mathrm{mg} / \mathrm{kg})$ was administered i.p. to animals of all the groups. The jerking of the head together with spasm of the facial muscles was taken to be the minimum convulsive response.

\section{Observations and Results}

1. Blind Neuropharmacological Screening and Behavioural Tests: The effects essentially suggested a central nervous system depressant activity in albichinoside in a number of parameters. (Table 1)

Table 1: Effects of albichinoside in blind neuropharmacological screening and behavioural tests

\begin{tabular}{|l|c|c|c|c|}
\hline S. No & Parameter & \multirow{2}{*}{ Effect } & \multicolumn{2}{|c|}{ Number of animals showing effect } \\
\cline { 3 - 4 } & & & $1.0 \mathrm{mg} / \mathrm{kg}$ & $5.0 \mathrm{mg} / \mathrm{kg}$ \\
\hline 1. & Alertness & Decreased & 0 & $5 / 5$ \\
\hline 2. & Grooming & Decreased & 0 & $5 / 5$ \\
\hline 3. & Spontaneous activity & Decreased & 0 & $5 / 5$ \\
\hline 4. & Pain response & Decreased & 0 & $5 / 5$ \\
\hline 5. & Change in gait & - & 0 & $5 / 5$ \\
\hline 6. & Tone of muscles & Slight decrease & 0 & $5 / 5$ \\
\hline 7. & Grip Strength & Slight decrease & 0 & $5 / 5$ \\
\hline 8. & Time of peak activity(min) & - & - & 90 \\
\hline
\end{tabular}

Data is represented as mean \pm SEM, $p=$ Probability of no significance as compared to control $(n=5)$.

2. Effect on Potentiation of Pentobarbitone hypnosis: Albichinoside (ALB) $(\mathrm{p}<0.01)$ and Chlorpromazine (CPZ) $(\mathrm{P}<0.001)$ showed significant potentiation of Hypnosis induced with pentobarbitone sodium. Albichinoside prolonged the sleeping time by 24.0 minutes over the control meaning an increase of $151.9 \%$. (Table 2 and Fig. 2)

3. Effect on Spontaneous Motor Activity (SMA): Albichinoside significantly reduced SMA in relation to control sixty minutes after its administration. The significant effect was maintained for up to 4 hours and probably beyond. (Table 3 and Fig. 3)

Table 2: Effect of albichinoside on potentiation of pentobarbitone sodium sleeping time in albino mice. Pentobarbitone sodium $(35.0 \mathrm{mg} / \mathrm{kg}$ i.p injected at the time of peak drug effect)

\begin{tabular}{|l|c|c|c|c|}
\hline S. No. & Group & Mean sleeping (min) & Prolongation & \\
\hline & & & Min. & \% \\
\hline 1. & Control (Vehicle) & $15.8 \pm 4.3$ & - & 0 \\
\hline 2. & CPZ $(5.0 \mathrm{mg} / \mathrm{kg})$ & $45.5 \pm 4.2$ & 29.7 & $187.9 * *$ \\
\hline 3. & ALB $(5.0 \mathrm{mg} / \mathrm{kg})$ & $39.8 \pm 3.8$ & 24.0 & $151.9 *$ \\
\hline
\end{tabular}

Data is represented as mean \pm SEM, where * represents $\mathrm{p} \leq 0.01$, ** represents $\mathrm{p} \leq 0.001$ when compared with control $(n=5)$ 


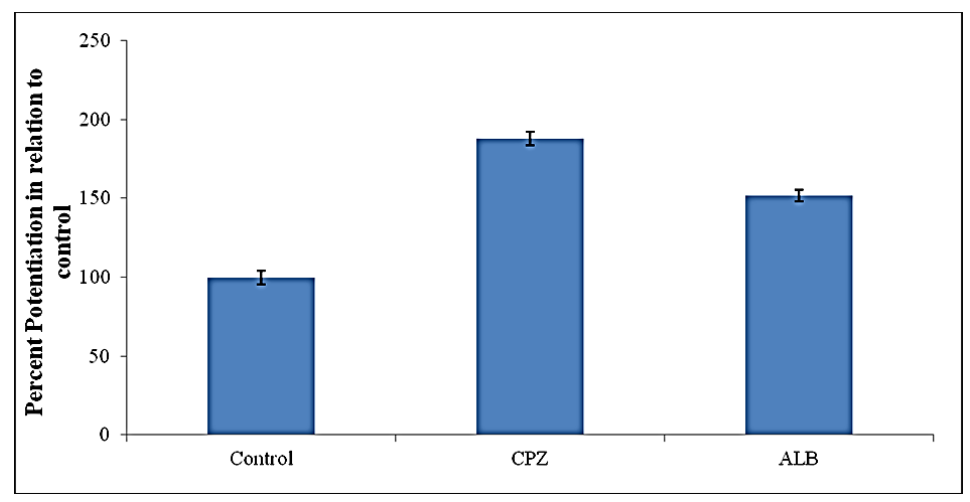

Fig. 2: Effect of albichinoside on pentobarbitone sodium sleeping time in albino mice. Data is represented as mean \pm SEM

Table 3: Effect of albichinoside on spontaneous motor activity in albino rats

\begin{tabular}{|l|c|c|c|c|c|c|c|c|}
\hline S. No. & Group & \multirow{2}{*}{$\begin{array}{c}\text { Average } \\
\text { activity count } \\
\end{array}$} & & \multicolumn{6}{|c|}{$\begin{array}{c}\text { Motor activity after administration of drugs. Mean of 10 min. count } \pm \\
\text { SEM at various time intervals (min.) }\end{array}$} \\
\cline { 5 - 9 } & & & $\mathbf{3 0}$ & $\mathbf{6 0}$ & $\mathbf{9 0}$ & $\mathbf{1 2 0}$ & $\mathbf{1 8 0}$ & $\mathbf{2 4 0}$ \\
\hline 1. & Control & 486.0 & 481.0 & 448.0 & 429.0 & 352.0 & 358.0 & 440.0 \\
& $($ Vehicle) & \pm 58.5 & \pm 71.7 & \pm 49.7 & \pm 50.1 & \pm 21.8 & \pm 34.6 & \pm 45.5 \\
\hline 2. & $\mathrm{CPZ}$ & 612.0 & 232.0 & 43.0 & 27.0 & 10.0 & 30.0 & 32.0 \\
& $(5.0 \mathrm{mg} / \mathrm{kg})$ & \pm 46.1 & $\pm 67.2^{*}$ & $\pm 13.6^{* *}$ & $\pm 16.5^{* *}$ & $\pm 5.0^{* *}$ & $\pm 15.3^{* *}$ & $\pm 10.3^{* *}$ \\
\hline 3 & $\mathrm{ALB}$ & 536.0 & 211.0 & 132.0 & 73.0 & 36.0 & 31.0 & 28.0 \\
& $(5.0 \mathrm{mg} / \mathrm{kg})$ & \pm 17.8 & $\pm 37.6^{*}$ & $\pm 28.7^{* *}$ & $\pm 31.0^{* *}$ & $\pm 17.5^{* *}$ & $\pm 13.4^{* *}$ & $\pm 12.7^{* *}$ \\
\hline
\end{tabular}

Data is represented as mean \pm SEM, where * represents $\mathrm{p} \leq 0.05$, $* *$ represents $\mathrm{p} \leq 0.001$, when compared with control $(\mathrm{n}=5)$

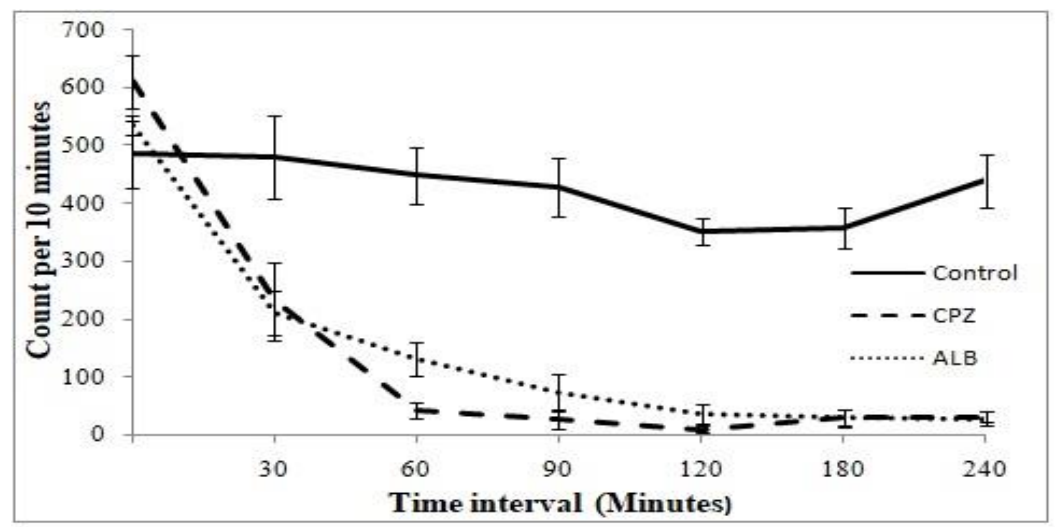

Fig. 3: Effect of albichinoside on spontaneous motor activity in albino mice. Data is represented as mean \pm SEM

4. Effect of Albichinoside on Amphetamine induced Hyperactivity.

Both albichinoside and chlorpromazine significantly antagonized the hyperactivity induced by amphetamine (Table 4, Fig. 4).

Table 4: Effect of albichinoside on amphetamine induced hyperactivity

\begin{tabular}{|c|c|c|c|c|c|c|c|c|c|}
\hline \multirow[t]{2}{*}{ S. No. } & \multirow[t]{2}{*}{ Group } & \multirow{2}{*}{$\begin{array}{l}\text { Average motor } \\
\text { activity before } \\
\text { drugs }\end{array}$} & \multirow{2}{*}{$\begin{array}{c}\text { Average motor } \\
\text { activity after } \\
\text { drugs }\end{array}$} & \multicolumn{6}{|c|}{$\begin{array}{l}\text { Motor activity after amphetamine injection Mean of } 10 \text { min. } \\
\text { count at various time intervals (min.) }\end{array}$} \\
\hline & & & & 30 & 60 & 90 & 120 & 180 & 240 \\
\hline \multirow[t]{2}{*}{1.} & Control & 227.0 & 202.0 & 592.0 & 735.0 & 648.0 & 584.0 & 553.0 & 536.0 \\
\hline & (vehicle) & \pm 7.9 & \pm 17.1 & \pm 79.8 & \pm 79.0 & \pm 70.7 & \pm 39.0 & \pm 22.6 & \pm 19.7 \\
\hline 2. & $\begin{array}{c}\mathrm{CPZ} \\
(5 \mathrm{mg} / \mathrm{kg})\end{array}$ & $\begin{array}{l}416.0 \\
\pm 10.8\end{array}$ & $\begin{array}{c}44.0 \\
\pm 11.7\end{array}$ & $\begin{array}{c}451.0 \\
\pm 127.4\end{array}$ & $\begin{array}{l}399.0 \\
\pm 95.2\end{array}$ & $\begin{array}{c}274.0 \\
\pm 84.7 * * \\
\end{array}$ & $\begin{array}{c}250.0 \\
\pm 46.3^{* * * *}\end{array}$ & \begin{tabular}{|c|}
311.0 \\
$\pm 9.9 * * *$
\end{tabular} & $\begin{array}{c}274.0 \\
\pm 45.6^{* *}\end{array}$ \\
\hline 3 & $\begin{array}{c}\mathrm{ALB} \\
(5 \mathrm{mg} / \mathrm{kg})\end{array}$ & $\begin{array}{l}307.0 \\
\pm 15.9\end{array}$ & $\begin{array}{l}63.0 \\
\pm 4.6\end{array}$ & $\begin{array}{c}239.0 \\
\pm 70.8^{*}\end{array}$ & $\begin{array}{l}322.0 \\
\pm 79.8\end{array}$ & \begin{tabular}{|c|}
273.0 \\
$\pm 67.9^{* * *}$ \\
\end{tabular} & $\begin{array}{c}210 \\
\pm 61.0^{* * * *}\end{array}$ & \begin{tabular}{|c|}
173.0 \\
$\pm 661.4^{* *}$
\end{tabular} & $\begin{array}{c}165.0 \\
\pm 51.6^{* *}\end{array}$ \\
\hline
\end{tabular}

Data is represented as mean \pm SEM, $(\mathrm{n}=5)$. Where * represents $\mathrm{p} \leq 0.05,{ }^{* *}$ represents $\mathrm{p} \leq 0.01,{ }^{* * *}$ represents $\mathrm{p} \leq$ 0.001 , when compared to control. 


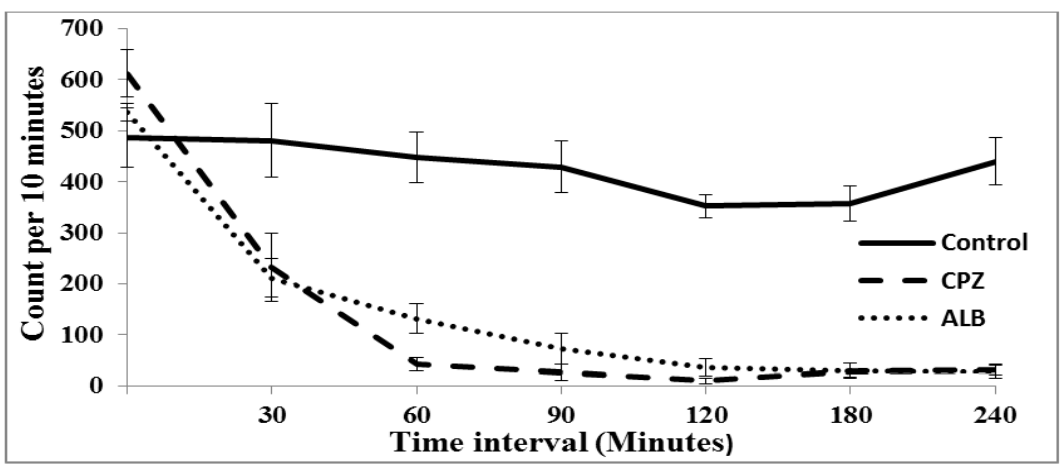

Fig. 4: Effect of albichinoside on amphetamine induced hyperactivity in albino mice. Data is represented as mean \pm SEM

\section{Effect on Conditioned Avoidance Response (CAR).}

Albichinoside blocked the conditioned avoidance response without affecting the unconditioned response (Table 5).

Table 5: Effect of albichinoside on conditional avoidance response

\begin{tabular}{|l|c|c|c|c|c|c|}
\hline \multirow{2}{*}{ S. No. } & \multirow{2}{*}{ Group } & \multicolumn{4}{|c|}{ Mean percent blockade of CAR at various time intervals (hours) Group index } \\
\cline { 3 - 7 } & & $\mathbf{1}$ & $\mathbf{2}$ & $\mathbf{3}$ & $\mathbf{4}$ & $\mathbf{5}$ \\
\hline 1. & Control (Vehicle) & 0 & 0 & 0 & 0 & 0 \\
\hline 2. & CPZ $(5.0 \mathrm{mg} / \mathrm{kg})$ & $55.6^{*}$ & $88.9^{* * *}$ & $72.2^{* *}$ & $66.7^{* *}$ & $66.7^{* *}$ \\
\hline 3 & ALB $(2.5 \mathrm{mg} / \mathrm{kg})$ & 11.1 & 11.1 & 16.7 & 11.1 & 11.1 \\
\hline 4. & ALB $(5.0 \mathrm{mg} / \mathrm{kg})$ & $44.4^{*}$ & $55.6^{*}$ & $66.7^{* *}$ & $66.7^{* *}$ & $44.4^{*}$ \\
\hline 5. & ALB $(10.0 \mathrm{mg} / \mathrm{kg})$ & $38.9^{*}$ & $66.7^{* *}$ & $83.3^{* * *}$ & $72.2^{* *}$ & $72.2^{* *}$ \\
\hline 6. & ALB $(20.0 \mathrm{mg} / \mathrm{kg})$ & $55.6^{*}$ & $61.1^{*}$ & $88.8^{* * *}$ & $83.3^{* * *}$ & $77.8^{* *}$ \\
\hline
\end{tabular}

Data is represented as mean \pm SEM, where $*$ represents $\mathrm{p} \leq 0.05, * *$ represents $\mathrm{p} \leq 0.01, * * *$ represents $\mathrm{p} \leq 0.001$, when compared to control $(n=10)$.

\section{Analgesic Effect}

a. Tail Flick Method: Albichinoside significantly increased the reaction time to thermal stimulus by the tail flick method though not in the hot plate model (Table 6, Fig. 5 \& Table 7, Fig. 6)

Table 6: Analgesic activity of albichinoside by tail flick method in albino rats

\begin{tabular}{|l|c|c|c|c|c|c|}
\hline S. No. & Group & \multirow{2}{*}{$\begin{array}{c}\text { Initial } \\
\text { reaction time (sec) }\end{array}$} & \multicolumn{3}{|c|}{$\begin{array}{c}\text { Reaction time after drug injection (in sec.) at various time } \\
\text { intervals (min.) }\end{array}$} \\
\cline { 4 - 7 } & & & $\mathbf{1 5}$ & $\mathbf{3 0}$ & $\mathbf{4 5}$ & $\mathbf{6 0}$ \\
\hline 1. & Control (Vehicle) & $7.0 \pm 0.2$ & $7.4 \pm 0.4$ & $7.6 \pm 0.2$ & $7.6 \pm 0.2$ & $7.2 \pm 0.4$ \\
\hline 2. & Morphine $(5 \mathrm{mg} / \mathrm{kg})$ & $6.9 \pm .0 .5$ & $12.4 \pm 1.4^{* *}$ & $12.8 \pm 0.6^{* * *}$ & $12.0 \pm 0.8^{* * *}$ & $12.6 \pm 0.7^{* * *}$ \\
\hline 3 & ALB $(5 \mathrm{mg} / \mathrm{kg})$ & $6.3 \pm 0.4$ & $9.2 \pm 1.3^{*}$ & $11.4 \pm 0.4 * * *$ & $11.6 \pm 0.7 * * *$ & $13.4 \pm 0.4 * * *$ \\
\hline
\end{tabular}

Data is represented as mean \pm SEM, where * represents $\mathrm{p} \leq .05, * *$ represents $\mathrm{p} \leq 0.01,{ }^{* * *}$ represents $\mathrm{p} \leq 0.001$ when compared to control $(\mathrm{n}=5)$

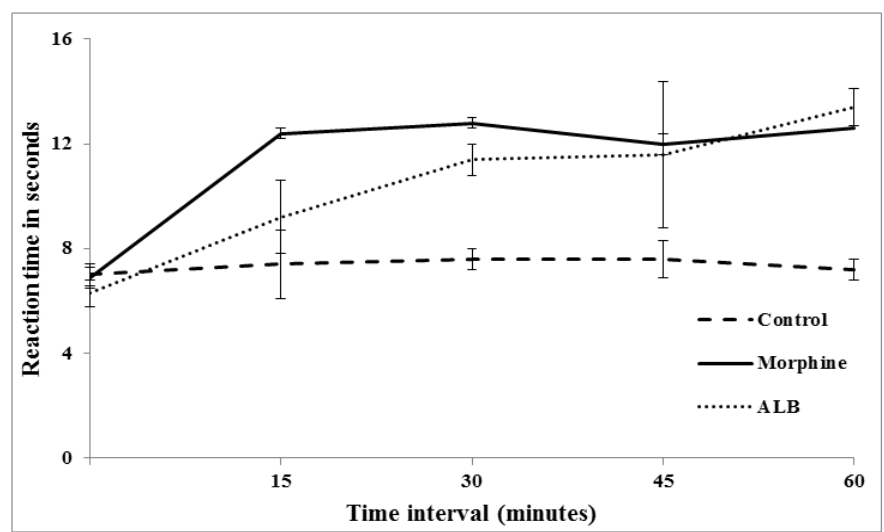

Fig. 5: Analgesic effect of albichinoside by tail flick method in albino rats. Data is represented as mean \pm SEM 


\section{b. Hot Plate Method}

Table 7: Analgesic effect of albichinoside by the modified method in albino mice

\begin{tabular}{|c|c|c|c|c|c|c|}
\hline \multirow[t]{2}{*}{ S. No. } & \multirow[t]{2}{*}{ Group } & \multirow{2}{*}{$\begin{array}{c}\text { Initial } \\
\text { reaction } \\
\text { time(sec.) }\end{array}$} & \multicolumn{4}{|c|}{$\begin{array}{c}\text { Reaction time after drug injection (in sec.) at various time } \\
\text { intervals (min) }(\text { Mean } \pm \text { SEM) }\end{array}$} \\
\hline & & & 5 & 10 & 15 & 30 \\
\hline 1. & Control (Vehicle) & $5.16 \pm 0.48$ & $4.5 \pm 1.0$ & $5.0 \pm 1.0$ & $3.0 \pm 1.4$ & $4.2 \pm 1.4$ \\
\hline 2. & $\begin{array}{c}\text { Sodium salicylate } \\
(400.0 \mathrm{mg} / \mathrm{kg})\end{array}$ & $5.8 \pm 0.5$ & $14.5 \pm 2.1 * *$ & $18.0 \pm 2.0 * * *$ & $20.5 \pm 3.2 * * *$ & $25.0 \pm 4.0 * * *$ \\
\hline 3 & ALB $(5.0 \mathrm{mg} / \mathrm{kg})$ & $5.5 \pm 0.5$ & $12.8 \pm 3.2 *$ & $9.8 \pm 4.0 *$ & $7.7 \pm 3.8^{*}$ & $7.8 \pm 5.0 *$ \\
\hline
\end{tabular}

Data is represented as mean \pm SEM, where * represents $\mathrm{p} \leq 0.05, * *$ represents $\mathrm{p} \leq 0.01$, ***represents $\mathrm{p} \leq 0.001$ when compared to control $(\mathrm{n}=5)$

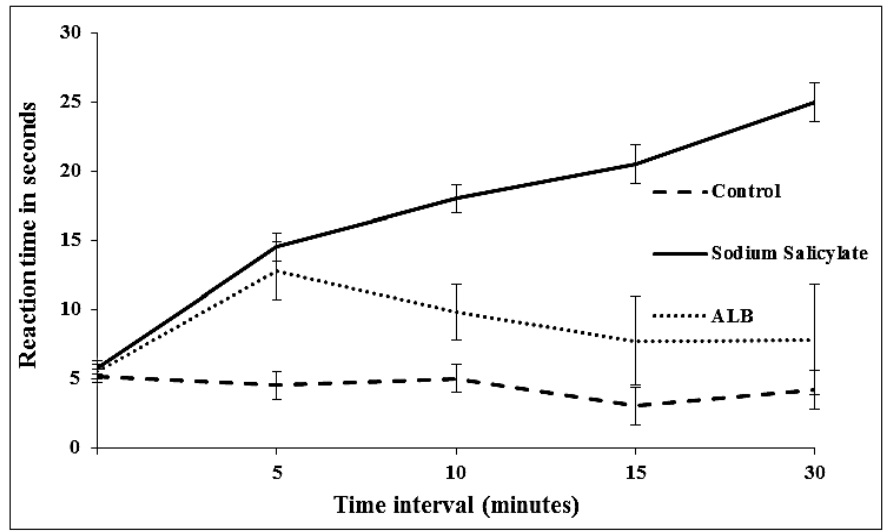

Fig 6: Analgesic effect of albichinoside by the modified hot-plate method in albino mice. Data is represented as mean \pm SEM

\section{Conclusion}

1. The saponin fraction, albichinoside, from the plant Albizzia chinensis potentiated pentobarbital hypnosis, reduced spontaneous motor activity, and also antagonized amphetamine induced hyperactivity in experimental animals. In all these tests the profile of the compound was akin to chlorpromazine.

2. In albino rats the compound blocked the conditioned avoidance response without affecting the unconditioned response.

3. Albichinoside showed analgesic activity by the tail flick method but not in hot plate model. The response was comparable to morphine.

4. Further, the compound revealed no anti-convulsant activity. The anti-convulsant effect was absent in both MES and PTZ models.

5. These observations suggest that the test compound albichinoside is more likely to possess tranquillizing properties similar to chlorpromazine.

\section{Summary}

In this study results, albichinoside produced central nervous system depression in various experimental designs that were carried out. It was partially effective as an analgesic and was devoid of anti-convulsant activity. Its profile was qualitatively similar to that of a major tranquillizer like chlorpromazine.

\section{References}

1. Irwin, S. (1959) Gordon. Res. Conf. Med. Chem. pp.133.

2. Kuhn, W.V. and van Mannen, E.P. (1961) J Pharmacol. Exp Ther. 134, 60.

3. Piala, J.J. High, J.P. Hassert, G.L. (Jr.), Burke, J.C. and Craver, B.N. (1959). J Pharmacol Exp Ther. 127, 55.

4. Brazada, F.G. and Baucum, R. (1961) J Pharmacol Exp Ther. 132, 295.

5. Harris,L.S. and Uhle, F.C. (1961). J Pharmacol Exp Ther. 132, 251.

6. Uski, S. and Sugeno, S. (1967). Jap J Pharmacol. 17,82.

7. Cook, L. and Weidley, E. (1957). Ann N.Y Acad Sci. 66, 740.

8. Davies, O.L., Raventos, J. and Walpole, A.L. (1946). Brit J Pharmacol. 1, 255.

9. Jacob, J. and Bosvki, M. (1961). Arch Intern Pharmacodyn. 133, 296.

10. Eddy, N. B. and Leimbach, D. (1953). J Pharmacol. Exp. Ther. 107, 385.

11. Toman, J.E.P., Swinyard, E.A. and Goodman, L.S. (1946). J Neurophysiol. 9. 232.

12. Soage - Echague, E. and Lim, R.K.S. (1962). J. Pharmacol Exp Ther. 138, 224. 